ORNL/TM-13454
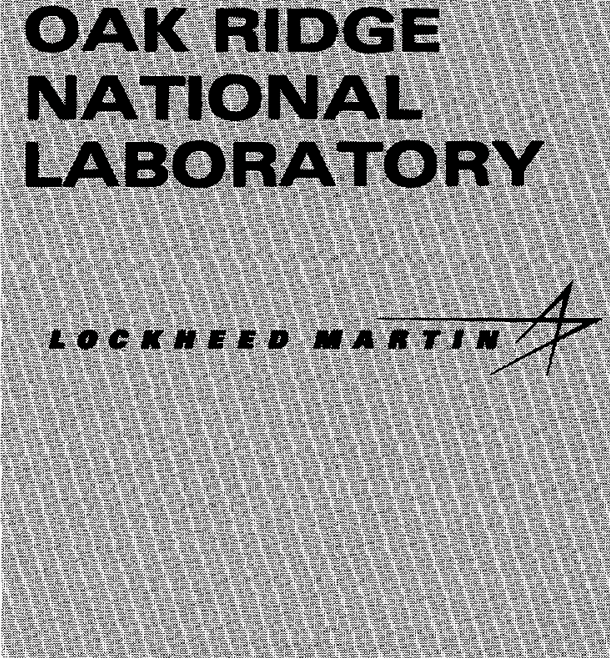

1.

\title{
Private Power Development and Environmental Protection in India
}

Sujit Das

Thomas J. Wilbanks

MNYAEED AND OPERATED BY

LOCKAEEO WARTIN ENERGY RESEARCH CORPORATON FOATHE UNTED STATES

DEPARTMENT OF ENERGY 
This report has been reproduced directly from the best alvailable copy.

Available to DOE and DOE contractors from the Office of Scientific and Technical Information, P.O. Box 62, Oak Ridge, TN 37831; prices available from (423) 576-8401, FTS 626-8401.

Available to the public from the National Technical Information Service, U.S. Department of Commerce, 5285 Port Royal Rd., Springfield, VA 22161.

This report was prepared as an account of work sponsored by an agency of the United States Government. Neither the United States Government nor any agency thereof, nor any of their employees, makes any warranty, express or implied, or assumes any legal liability or responsibility for the accuracy, completeness, or usefulness of any information, apparatus, product, or process disclosed, or represents that its use would not infringe privately owned rights. Reference herein to any specific commercial product, process, or service by trade name, trademark, manufacturer, or otherwise, does not necessarily constitute or imply its endorsement, recommendation, or favoring by the United States Government or any agency thereof. The views and opinions of authors expressed herein do not necessarily state or reflect those of the United States Government or any agency thereof. 


\section{PRIVATE POWER DEVELOPMENT AND ENVIRONMENTAL PROTECTION IN INDIA}

Sujit Das

Thomas J. Wilbanks

December 1997

Sponsored by

Office of Environment, Energy, and Enterprise

U.S. Agency for International Development/New Delhi

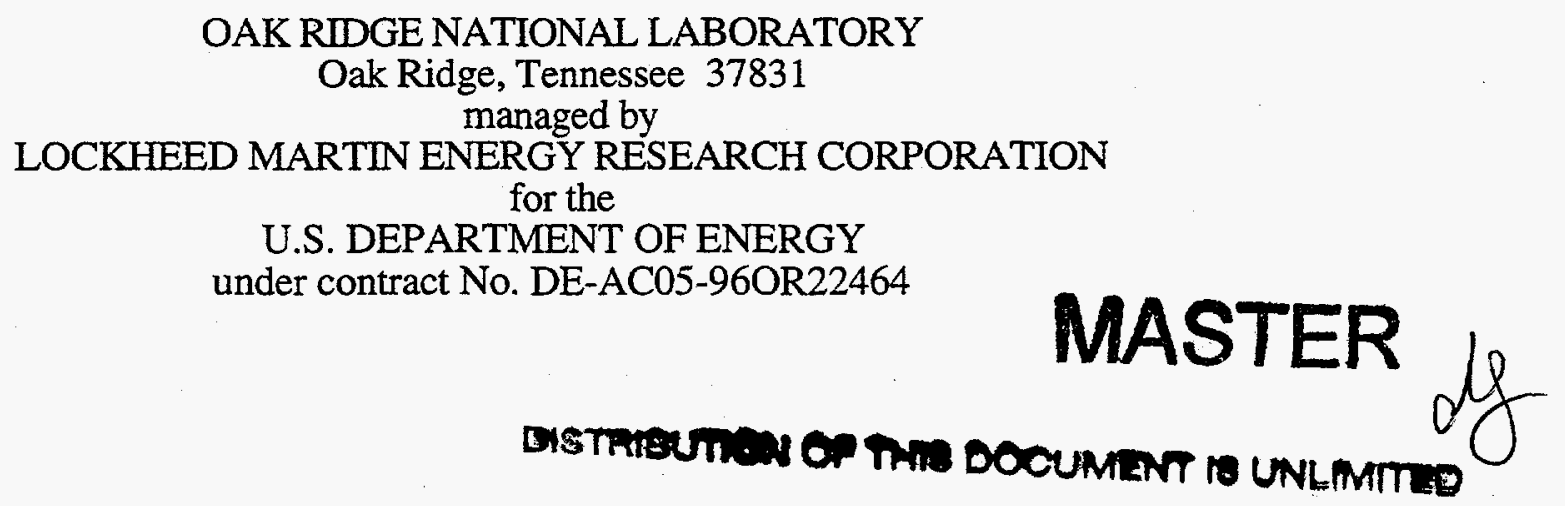




\section{DISCLAIMER}

Portions of this document may be illegible electronic image products. Images are produced from the best available original document. 


\section{CONTENTS}

$\underline{\text { Page }}$

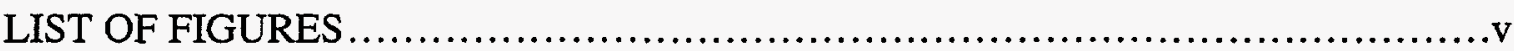

LIST OF TABLES.......................................................... vii

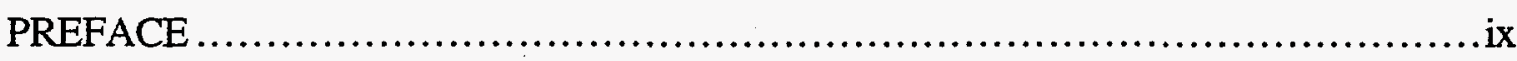

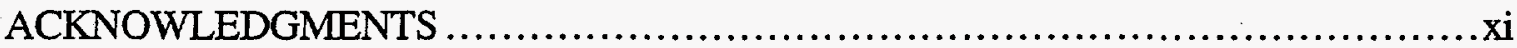

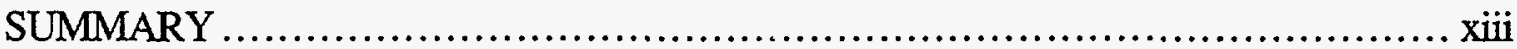

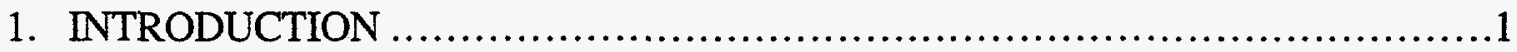

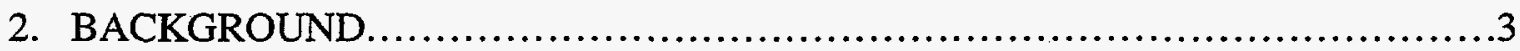

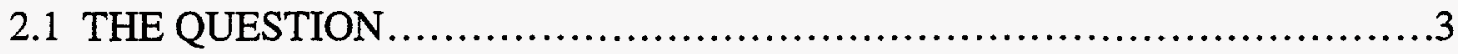

2.2 THE CONTEXT IN INDIA ..............................................4

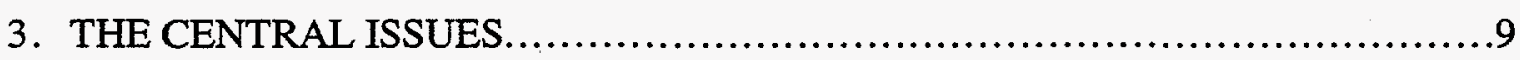

3.1 EFFECTIVE ENVIRONMENTAL REGULATION, MONITORING, AND ENFORCEMENT OF ELECTRIC POWER GENERATION ....................9

3.2 POSSIBLE DIFFERENCES BETWEEN PUBLIC AND PRIVATE POWER DEVELOPERS IN MANAGEMENT BEHAVIOR.

3.3 POSSIBLE DIFFERENCES BETWEEN PUBLIC AND PRIVATE POWER DEVELOPERS IN RESOURCE/TECHNOLOGY CHOICES FOR POWER

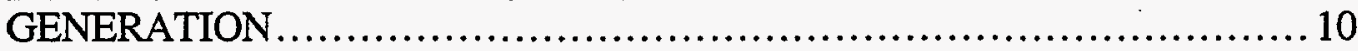

3.4 RELATIONSHIPS BETWEEN ELECTRICITY SERVICE RELIABILITY AND ENVIRONMENTAL POLLUTION AT END-USE LOCATIONS ...... 11

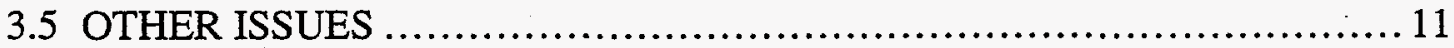

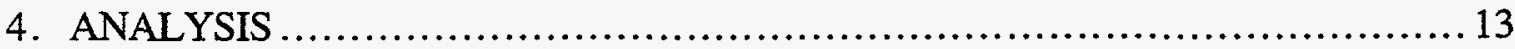

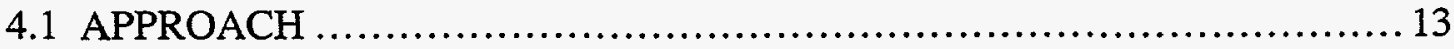

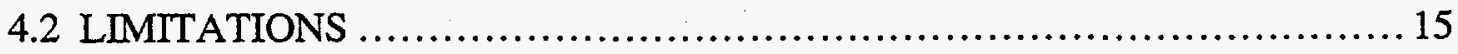

4.3 SCENARIOS......................................................... 17

4.4 SCENARIO RESULTS.............................................. 17

4.4.1 Private Power and Impacts of Power Generation in India ................25

4.4.2 Private Power and Environmental Quality in Urban Areas in India........26

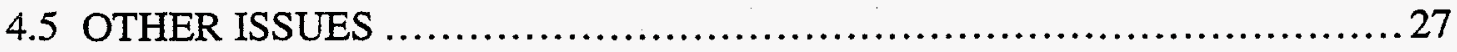


CONTENTS (Cont'd)

Page

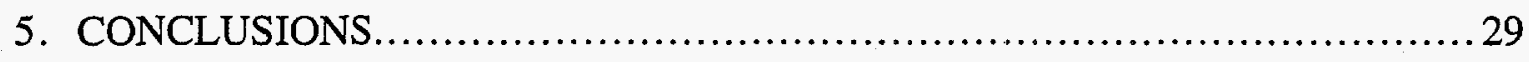

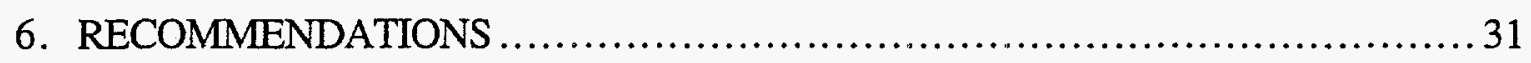

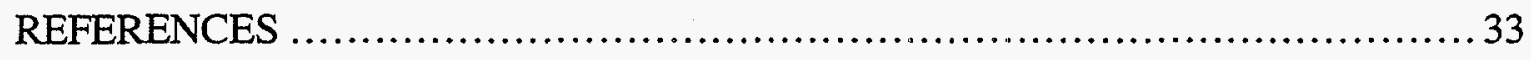

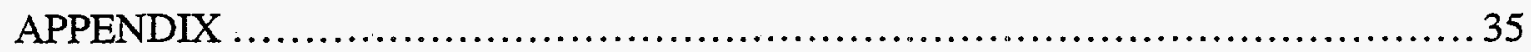




\section{LIST OF FIGURES}

Page

Fig. 1. Effect on uncontrolled air emissions due to the variation in specific coal consumption in Indian thermal power plants.

Fig. 2. Forecast of energy requirements in India during $2001-2012 \ldots \ldots \ldots \ldots \ldots \ldots \ldots \ldots$

Fig. 3. Distribution of sectoral power generation in India during 2001-2012:

scenario A

Fig. 4. Distribution of sectoral power generation in India during 2001-2012: scenario $\mathrm{B}$.

Fig. 5. Distribution of sectoral power generation in India during 2001-2012: scenario $\mathrm{C}$

Fig. 6. Distribution of sectoral power generation in India during 2001-2012: scenario D. 



\section{LIST OF TABLES}

Table 1. Installed power generating capacity and electricity generation in India during 1993-1994

Table 2. Forecasted electricity generating capacity additions (MW) by private power sector.

Table 3. Uncontrolled emission factors (tons/GWh) for different resource based power generation technologies in India

Table 4. Controlled emission factors (tons/GWh) for different resource based power generation technologies in India

Table 5. Forecasted air pollutant emissions ('000 tons) under four different scenarios during 2001-2012

Table 6. Forecasted air pollutant emissions (' 000 tons) under four different scenarios during 2001-2012

Table 7. Ratio of concentration of diesel generation to concentration of different utility based power generation technologies for various uncontrolled air pollutant emissions (for explanation, see Appendix) 



\section{PREFACE}

This report was prepared at the request of the Office of Environment, Energy, and Enterprise of the India Mission of the U.S. Agency for International Development (USAID) as a source of information and perspectives. It reflects a very limted effort of about one person-month; therefore its scope and aims are modest. The conclusions reached in the report are those of the authors and do not necessarily speak for USAID, the U.S. Department of Energy, or the Oak Ridge National Laboratory. 



\section{ACKNOWLEDGMENTS}

The authors wouild like to acknowledge helpful advice and comments from David Hess, N. V. Seshadri, Kavita Sinha, and Hugh McDermott of USAID/New Delhi; Gary Staats of the Federal Energy Technology Center; Sanjay Mohanty of the Tata Energy Research Institute; Keith Kozloff of Hagler, Bailly Services; and Robert L. Miller of ORNL. 



\section{SUMMARY}

Private power development is currently a relatively small part, i.e., less than $4 \%$ of total electricity supply system in India. With the projected demand of more than 140,000 MW (equivalent to 1.6 times the current capacity) in new power generation capacity by the end of 2007, privatization is gaining momentum as a problem-solving strategy because the private developers bring their own sources of investment capital and can often move faster than public institutions to meet urgent supply needs. The objective of this report is to assess whether private firms generating and distributing electricity to industry, commerce, agriculture, and home-owners in India, will do a better or a worse job in environmental protection as a part of their overall corporate responsibility, compared with public-sector institutions. It is intended to inform ongoing discussions of U.S. Agency for International Development (USAID) mission strategic objectives and performance indicators related to initiatives for both improved environmental management and increased power development in India.

The approach used in this study consisted at first review of the question, why it is being asked, and the context in which it operates in India. It then summarizes the central issues involved in considering relationships between private power development and environmental protection. It continues with an analysis of available information, quantitative and qualitative, that can help to resolve the issues in the particular case of India. A range of scenarios that represent different paths for meeting electricity service needs for economic and social development were examined as a basis for evaluating the environmental implications for private power development in India.

As long as private power generation in India remains more efficient in power plant performance than public power generation, its air emissions will be less - if the use of generation technologies is more or less comparable. For example, under the optimistic private power growth scenario particulate matter emissions are estimated to only about onequarter of the total emissions in 2011-2012 compared with the base case. Solid waste production will be about the same, public vs. private. Uncontrolled emissions from diesel generators by industrial, commercial, and residential customers due to a lack of reliable central power supplies are bad for the environment in India, compared with controlled emissions from central power plants. The uncontrolled emissions occur in locations where air pollution is already the worst, added to such other sources as local vehicle emissions, rather than at power plant sites, where ambient conditions are usually less critical.

It is concluded that private power development in India under foreseeable conditions is more likely to make a positive contribution to national environmental 
management in India than a negative one. At least initially, responsible environmental management will be driven more by social scrutiny and corporate image than by government regulation. The greatest environmental dangers from private power development in India lie in ad hoc domestic private sector responses to a national power crisis, based on coal use, if such a crisis provokes a "crash" private power expansion program with a relaxation of standards.

To reduce uncertainties surrounding the conclusions arrived in this report, it is recommended that USAID/New Delhi should gather information to support a comparison of the management efficiency and environmental effects of equivalent public vs. Private fossil-fueled power plants in India, with attention to possible differences between international and domestically financed power plants. Enhancement of the information base about environmental effects in urban areas of unreliable central sources of electricity services, especially impacts of industrial, commercial, and residential self-generation is highly recommended. 


\section{INTRODUCTION}

Prepared for the Mission to India of the U.S. Agency for International Development (USAID), this report assesses relationships between private power development in India and environmental protection in that country. It is intended to inform ongoing discussions of Mission strategic objectives and performance indicators related to initiatives for both improved environmental management and increased private power development in India.

Because private power development is a relatively small part of the electricity supply system in India at this stage, the assessment rests on a number of assumptions about future paths that will need continuing attention by the Mission in years to come. On the other hand, the report's general conclusion -- that private power development under foreseeable conditions is more likely to make a positive contribution to national environmental management in India than a negative one -- seems robust enough to use as a basis for USAID strategic planning for the current planning period and beyond.

This report first reviews the fundamental question, why it is being asked, and the context in which it operates in the nation of India. It then summarizes the central issues involved in considering relationships between private power development and environmental protection. It continues with an analysis of available information, quantitative and qualitative, that can help to resolve the issues in the particular case of India. Finally, it ends with conclusions from the analysis and recommendations for reducing remaining uncertainties in the future.

Since the report was prepared over a brief period of time, with very limited opportunities for data-gathering and consultation with others, including coordination with an ongoing study of the same issues at a global scale by Hagler Bailly Services, Inc. for USAID's Global Bureau (Hagler Bailly Services, 1997), it should be considered a first cut rather than the final word on the subject. In particular, it should be noted that -- compared with the Hagler, Bailly study -- this exercise is focused on a relatively narrow question, the environmental effects of private power plant development (the what) rather than on the broader question, environmental effects of electric power sector reform (the how, which will shape the context for the what). 



\section{BACKGROUND}

\subsection{THE QUESTION}

The central question is whether private firms generating and distributing electricity to industry, commerce, agriculture, and home-owners in developing countries will do a better or a worse job in environmental protection, as a part of their overall corporate responsibility, than public-sector institutions.

The question of relationships between private power development and environmental protection is both ideological and empirical. In terms of ideology, many developing countries consider electricity services to be a fundamental component of the development process, social goods that should be provided in ways attuned to social needs and modes of operation rather than to market forces. The idea of making a profit from the provision of social goods and services such as electric power has attracted particular criticism. As a result, historically most developing countries have chosen to use public sector institutions to provide social goods and services, believing that such institutions are more responsive and more accountable to social priorities than are private firms, and electric utilities have been as central to this philosophy as, say, water, transportation, or communications services.

Since the mid-1980's, however, this philosophy has come under increasing reexamination, as public institutions in developing countries (and elsewhere) have so often proven to be inefficient and financially shaky. Worldwide, the trend is for government to try to do less better, and a leading aspect of this trend is the privatization of many public functions.

Among these functions, electric utilities are among the most capital intensive sectors in a developing economy; and many utilities in developing countries are sinking under burdens of overemployment and underpricing. With demand growing for electricity services, not only for industrial growth but also for consumer comfort and convenience, these public utilities are unable to borrow the capital necessary for expansion. As a result, many countries are taking a fresh look at private electric power development, because the private developers bring their own sources of investment capital and can often move faster than public institutions to meet urgent power supply needs. USAID and the multilateral donors have generally encouraged this process.

At the same time that privatization is gaining momentum as a problem-solving strategy for developing countries, environmental deterioration is a serious problem for many of these countries. Especially in regions showing rapid economic growth, such as 
Asia, the volume of environmental emissions is growing dramatically; and the protection of the environment and of human health is becoming a critical issue. Again, USAID and the multilateral donors have advocated strong and effective action in this arena of policy and decisionmaking.

Some observers argue that these two directions -- (a) privatization, especially of large-scale productive activities, and (b) environmental protection -- are fundamentally at odds. The philosophy of these observers is that private firms are motivated by profit margins, market shares, and returns on stockholder investment; and, given an opportunity, many firms will sacrifice environmental protection in the interest of these other objectives -in contrast to public institutions, whose "stockholders" are the public and whose "profit margins" lie in public support for their mandate to provide services. These observers feel that widespread privatization reduces the control by government and society at large of productive activities and their impacts, including environmental pollution; and they advocate a strategy that emphasizes making public institutions more effective rather than transferring their functions to private firms.

The question addressed in this report is whether such a position based in political philosophy and the historical experience of the industrial revolution is supported or contradicted by current empirical evidence in India.

\subsection{THE CONTEXT IN INDIA}

India has long been a complex mixture of public and private sector roles in the national economy. Alongside a vigorous private sector, historically focused mainly on the large domestic market (protected by import tariffs and other policies), the public sector has reserved a wide variety of functions related to the social infrastructure for development, such as transportation and communication. Some of the public sector organizations have been well-managed, such as the Indian railways, and some organizations compete in national markets very much like private firms (e.g., BHEL).

Before Indian independence, private electric utilities arose in many parts of the country; but their roles diminished after the Industrial Policy Resolution of 1956, which designated most aspects of electric power generation and distribution to be exclusive responsibilities of the states. Today, only five of the private utilities originally licensed under the 1910 Electricity Act -- Bombay Suburban Electric Supply and Tata Electric Companies in Mumbai, Ahmedabad Electricity Company, Surat Electric Company, and the Calcutta Electric Supply Corporation -- are still in operation. 
As shown in Table 1, the total installed electricity generating capacity of India was 76,752 MW in 1993-94, with less than 4 percent supplied by the private utilities. Power supplied in that year is estimated to have been $324 \mathrm{TWh}$. Generating capacity has grown at an average rate of 9.3 percent since 1950 , and more than 50 percent of current capacity has been added since 1980 . Overall, generating capacity is dominated by thermal power facilities, which supply about two-thirds of current electric power, while the hydroelectric power share has shrunk for a variety of reasons, both economic and environmental.

With India's healthy economic growth, especially since the economic reforms of 1992, future needs for electric power to support the development process are daunting. For example, it is widely agreed that India will need to add more than $140,000 \mathrm{MW}$ in new power generation capacity by the end of the 10th Five Year Plan (2007) in order to meet development needs, nearly twice the current total capacity, at an estimated cost of $\$ 200$ billion.

In recent years, however, electricity shortages from public utility sources have become a serious national problem. In 1993/94, the all-India peak shortage was 18 percent and the baseload deficit was 7.3 percent (TERI, 1996). Power plant availability and efficiency are generally low, and system losses throughout India's transmission and distribution (T\&D) network absorb 20 percent or more of the country's power generation.

Inefficiencies in the power system are often matched by poor financial performance of India's public utilities; and commercial losses by the State Electricity Boards (SEBs) are rising, reaching the equivalent of $\$ 2.2$ billion in FY 1996, or about 0.8 percent of India's GDP (World Bank, 1996). Frequently, SEBs have an inadequate capital structure, tariffs that do not recover marginal costs, and poor records of bill collection, while they continue to be required by state governments to fulfill functions for which they are not fully compensated. Due to their financial weakness, Indian public utilities have found it increasingly difficult to borrow in order to add new power generation capacity to keep pace with demand growth.

One consequence has been a steady rise in electricity generation by non-utility sources: especially industrial and commercial establishments needing reliable power supplies and assuring these supplies by installing their own generating equipment. Nonutility generation in India is estimated to have equaled about 10 percent of utility power generation in 1993-94, and generating capacity is estimated at about 12 percent of utility capacity (Table 1). In addition, self-generation is growing in the residential and small commercial sectors, based heavily on the use of inefficient small generators with no emission controls. 
Table 1. Installed power generating capacity and electricity generation in India during 1993-1994

a

\begin{tabular}{|c|c|c|c|c|c|c|c|c|}
\hline & \multicolumn{4}{|c|}{ Generating capacity (MW) } & \multicolumn{4}{|c|}{ Electricity generation (MWH) } \\
\hline $\begin{array}{c}\text { Generation } \\
\text { type }\end{array}$ & $\begin{array}{c}\text { Public } \\
\text { utilities }\end{array}$ & $\begin{array}{l}\text { Private } \\
\text { utilities }\end{array}$ & Non-utilities & Total & $\begin{array}{l}\text { Public } \\
\text { utilities }\end{array}$ & $\begin{array}{l}\text { Private } \\
\text { utilities }\end{array}$ & Non-utilities & Total \\
\hline Hydro & $\begin{array}{l}20085 \\
(98 \%)\end{array}$ & $\begin{array}{c}294 \\
(2 \%)\end{array}$ & $\bar{X}$ & $\begin{array}{c}20379 \\
(100 \%)\end{array}$ & $\begin{array}{l}68970 \\
(98 \%)\end{array}$ & $\begin{array}{l}1493 \\
(2 \%)\end{array}$ & $\bar{X}$ & $\begin{array}{c}70463 \\
(100 \%)\end{array}$ \\
\hline Steam & $\begin{array}{l}46678 \\
(85 \%)\end{array}$ & $\begin{array}{l}2468 \\
(4 \%)\end{array}$ & $\begin{array}{l}5793 \\
(11 \%)\end{array}$ & $\begin{array}{c}54939 \\
(100 \%)\end{array}$ & $\begin{array}{c}221584 \\
(84 \%)\end{array}$ & $\begin{array}{l}11566 \\
(4 \%)\end{array}$ & $\begin{array}{l}29408 \\
(11 \%)\end{array}$ & $\begin{array}{l}262558 \\
(100 \%)\end{array}$ \\
\hline $\begin{array}{l}\text { Diesel \& } \\
\text { wind }\end{array}$ & $\begin{array}{c}337 \\
(8 \%)\end{array}$ & $\begin{array}{c}2 \\
(0 \%)\end{array}$ & $\begin{array}{c}3995 \\
(92 \%)\end{array}$ & $\begin{array}{c}4334 \\
(100 \%)\end{array}$ & $\begin{array}{c}311 \\
(8 \%)\end{array}$ & $\mathrm{X}$ & $\begin{array}{c}3834 \\
(92 \%)\end{array}$ & $\begin{array}{c}4145 \\
(100 \%)\end{array}$ \\
\hline Gas & $\begin{array}{c}4624 \\
(95 \%)\end{array}$ & $\begin{array}{c}259 \\
(5 \%)\end{array}$ & $\mathrm{X}$ & $\begin{array}{c}4883 \\
(100 \%)\end{array}$ & $\begin{array}{l}13934 \\
(95 \%)\end{array}$ & $\begin{array}{c}794 \\
(5 \%)\end{array}$ & $\bar{X}$ & $\begin{array}{c}14728 \\
(100 \%)\end{array}$ \\
\hline Nuclear & $\begin{array}{c}2005 \\
(100 \%)\end{array}$ & $\bar{X}$ & $\bar{X}$ & $\begin{array}{c}2005 \\
(100 \%)\end{array}$ & $\begin{array}{c}5398 \\
(100 \%)\end{array}$ & $\mathrm{X}$ & $\mathrm{X}$ & $\begin{array}{c}5398 \\
(100 \%)\end{array}$ \\
\hline Other & $\bar{X}$ & $\mathrm{X}$ & $\begin{array}{c}787 \\
(100 \%)\end{array}$ & $\begin{array}{c}787 \\
(100 \%)\end{array}$ & $\bar{X}$ & $\bar{X}$ & $\begin{array}{c}3121 \\
(100 \%)\end{array}$ & $\begin{array}{c}3121 \\
(100 \%)\end{array}$ \\
\hline Total & $\begin{array}{l}73729 \\
(84 \%)\end{array}$ & $\begin{array}{l}3023 \\
(4 \%)\end{array}$ & $\begin{array}{l}10575 \\
(12 \%)\end{array}$ & $\begin{array}{c}87327 \\
(100 \%) \\
\end{array}$ & $\begin{array}{c}310197 \\
(86 \%)\end{array}$ & $\begin{array}{c}13853 \\
(4 \%)\end{array}$ & $\begin{array}{l}36363 \\
(10 \%)\end{array}$ & $\begin{array}{l}360413 \\
(100 \%)\end{array}$ \\
\hline
\end{tabular}

Source: CEA (1995) and TERI (1996). 
Because of the growing gap between public sector power supply capabilities and national development needs, along with diminishing investment resources available to the public sector, in 1991 the government of India opened the power sector to private sector participation in electricity generation, transmission, and distribution. Since then, and especially in recent years, more than 300 proposals have emerged, offering private investment and other forms of involvement by private firms, totaling nearly 130,000 MW in generating capacity (Table 2). Despite this level of interest, however, only a few agreements have been concluded; and several widely-publicized large international "fasttrack" project proposals are still awaiting final government action on requests for investment counter-guarantees.

One characteristic of many of these proposals is the use of natural gas, which has represented only a small share of India's power generation in the past (Table 2), and oil is also receiving considerable attention. On the other hand, coal is India's most abundant source of energy. The current production level is 350,000 million tons per year, meeting more than 56 percent of the country's primary energy needs; and coal will continue to be the primary fuel choice for the foreseeable future, especially for public utilities. The electric utility sector consumes almost 60 percent of the coal produced. Indian coal is generally of low grade, with low calorific value and high ash and moisture content, requiring relatively large quantities of coal to be consumed per unit of electricity generated, relatively large quantities of particulate emissions to the environment, and relatively large volumes of ash for disposal.

Regardless of the mix of energy sources, both public and private power development will evolve in the midst of widespread economic and electricity restructuring in India; and its environmental impacts will depend substantially on what happens in other segments of the nationai system for electricity supply and use. For example, loss reduction in distribution systems through vertical deintegration and privatization may reduce power plant emissions per unit of electricity supplied, and private distribution systems may influence the public/private sector mix in power generation. In addition, tariff reforms should encourage end-use efficiency improvements. Many of these issues and their environmental implications are discussed -- from opposing points of view -- in recent reports by the World Bank (1996) and the Institute for Policy Studies (1996).

Power development will also occur in a time of increasing national attention to environmental policy and regulation. Stimulated by recent judgments of the Indian Supreme Court, and further encouraged by such commitments as the Indo-U.S. Common Agenda for the Environment, electric power generation by utilities is certain to receive closer environmental monitoring in the future than in the past. 
Table 2. Forecasted electricity generating capacity additions (MW) by private power sector

\begin{tabular}{|c|c|c|c|}
\hline $\begin{array}{c}\text { Generation } \\
\text { type }\end{array}$ & $\begin{array}{c}\text { Existing utility } \\
\text { capacities } \\
(1993-94)\end{array}$ & $\begin{array}{c}\text { Offered for private } \\
\text { sector investment by } \\
\text { the govt. of India }\end{array}$ & $\begin{array}{c}\text { Interests offered by } \\
\text { private sector } \\
\text { companies }\end{array}$ \\
\hline Thermal & $49,146(64 \%)$ & $16,570(27 \%)$ & $50,430(67.0 \%)$ \\
\hline Gas & $4,883(6 \%)$ & $16,915(28 \%)$ & $11,694(15.5 \%)$ \\
\hline Hydro & $20,379(27 \%)$ & $27,770(45 \%)$ & $6,850(9.2 \%)$ \\
\hline Oil & $339(<1 \%)$ & $\bar{X}$ & $6,256(8.3 \%)$ \\
\hline Nuclear & $2005(3 \%)$ & $\bar{X}$ & $\mathbf{X}$ \\
\hline Total & $\begin{array}{c}\mathbf{7 6 , 7 5 2} \mathbf{M W} \\
(\mathbf{1 0 0 \% )}\end{array}$ & $\begin{array}{c}\mathbf{6 1 , 2 5 5} \mathbf{M W} \\
(\mathbf{1 0 0 \%})\end{array}$ & $\begin{array}{c}\mathbf{7 5 , 2 3 0} \mathbf{M W} \\
(\mathbf{1 0 0} \%)\end{array}$ \\
\hline
\end{tabular}

Source: CBIP (1995). 


\section{THE CENTRAL ISSUES}

The question of relationships between electricity sector privatization and environmental protection is related to several central issues.

\subsection{EFFECTIVE ENVIRONMENTAL REGULATION, MONITORING, AND ENFORCEMENT OF ELECTRIC POWER GENERATION}

One of the most profound lessons of the past century and a half in political economics is that the public interest is best served when the private sector operates within a set of rules to protect the public. Private power development is unlikely to be good for the environment unless the government, representing the public, puts in place a set of policies and implementation structures that define a set of expectations about environmental protection and assure that those expectations are met. Private firms are very good at understanding the rules of the game and working within them. For environmental management, the question is whether those rules are clear about this particular national priority. Simply stated, private power development is far more likely to be good for the environment when it takes place in the context of effective environmental regulations, enforced where necessary. Even though the enforcement of environmental regulations in India is still spotty, private power projects (at least the larger ones involving foreign investment) receive especially stringent environmental review and scrutiny, both at the proposal stage and in operation.

\subsection{POSSIBLE DIFFERENCES BETWEEN PUBLIC AND PRIVATE POWER DEVELOPERS IN MANAGEMENT BEHAVIOR}

- Objectives. Even where private power developers are willing in principle to pay attention to environmental protection, they are expected by their owners and shareholders to earn a profit. When environmental protection imposes a cost on operations and other factors begin to squeeze the economic calculus, private developers may choose to cut corners on the environmental side in order to sustain the flow of power to their buyers without jeopardizing profits. In other words, investments in environmental protection may not be considered high priorities; in fact, in some cases, they may be considered luxuries, to be implemented only after a number of more important concerns are taken care of. In this sense, private power is the captive of its investors, interested in a return on their investment, rather than being a service to the public, and the environment may be a 
casualty. The issue is whether this behavioral motive -- perhaps stimulated by an emphasis on cost-competitiveness in a newly restructured electricity system marketplace -- is likely to overshadow others, such as concerns about corporate image and possible costs associated with public-sector enforcement of environmental laws and regulations.

- Accountability. It has been argued within the international development community, especially by NGOs, that public utilities -- as extensions of government -- are necessarily responsive to government policies, in letter and spirit, because they belong to the government. Private power developers are, by definition, more independent -- less controlled by government decisionmakers. Where government is ahead of the private sector in its focus on environmental protection, this could mean that private power developers will be less responsive to stated government policies than public power developers.

- Management effectiveness. One of the foremost challenges in effective environmental management in India's SEBs is their management limitations. By contrast, virtually every private power project is associated with management structures that are better at achieving any institutional objective, including environmental protection. In increasing its share of power supply in India, private power development establishes models and management standards that can eventually be spread throughout the electricity sector.

- Responsibility. Even when the government tries to be clear and consistent, the private sector can often get around public policy by strategies that range from legal obfuscation to bribery. As a general rule, then, the prospects for private power development to be good for the environment depend partly on the culture of the private sector involved -- its belief in the importance of the national interest and of the environment, its concern about public accountability, its interest in competing by being more effective within the rules rather than by being more ingenious in getting around them. Whether or not this is the case in India can be argued.

\subsection{POSSIBLE DIFFERENCES BETWEEN PUBLIC AND PRIVATE POWER DEVELOPERS IN RESOURCE/TECHNOLOGY CHOICES FOR POWER GENERATION}

It is widely believed that opening doors for private power development will mean more proposals for decentralized power generation from localized renewable energy sources, such as biomass cogeneration, small hydro, and windpower; and the early experience with private power in most developing countries seems to support this view. If so, private power is likely to be less environmentally damaging than public power based on 
conventional sources. For the time being, however, the largest proportion of new private power generation proposals in India are based on the use of fossil fuels. The main distinction seems to be between international project proposals based on imported fuels, coal or gas, and domestic proposals based on Indian coal.

\subsection{RELATIONSHIPS BETWEEN ELECTRICITY SERVICE RELIABILITY AND ENVIRONMENTAL POLLUTION AT END-USE LOCATIONS}

The current emphasis on private power plant development in India and other developing countries is one of two main responses to the fact that traditional infrastructures are not able to expand the supply of electricity services as economic development increases the demand (the other main response is efficiency improvement). Meanwhile, in a great many cases the way development is proceeding in the absence of adequate electricity services from utilities and other central sources is through self-generation: industrial, commercial, and residential. Based very largely on diesel generators with no emission controls, this decentralized response to inadequate public power supply is a major contributor to urban environmental pollution in India. To the degree that private power development improves central power supply, it will reduce the use of environmentally damaging (and economically expensive) decentralized self-generation by diesel generators.

\subsection{OTHER ISSUES}

- Standard-setting. The early ventures in international private power development in India appear to be serving as highly scrutinized, highly publicized examples of meeting environmental protection requirements to the fullest degree. In a very real sense, they are setting a new standard for power plant construction and operation in India; and it seems very likely that the substantial public curiosity (and skepticism) about their social benefits and costs will assure both that their environmental impacts stay within regulatory guidelines and that their approaches and their records will be widely publicized.

- International corporate image. One of the ideas behind private power development is to attract sources of international capital that are unwilling to invest in SEB or National Thermal Power Corporation (NTPC) power plant projects. In most cases, these international partners are highly sensitive to their public images; and environmental, health, and safety protection are central to that concern. No international power plant investor wants to be associated with an environmental Bhopal, and its involvement in a power 
project is very likely to increase the vigilance of the project relative to environmental management.

- Impetus for an environmental technology industry. A growing private power movement is likely to spawn private sector initiatives in India to provide environmental management services to private power plants, such as emission monitoring and waste management such as fly ash utilization; and these entrepreneurs will then market their services throughout the electricity sector, thereby improving environmental protection in some parts of the public power supply system as well. The fly ash utilization market has a huge potential in India.

- Bellwether indicator. Besides these relatively direct reasons why private power could be good for the environment, it can also be argued that an increase in the proportional contribution of private power to total central power generation in India is a strong indicator of progress in revising public policies, procedures, and other rules of the game to close the gap between Indian and international practice, which should benefit environmental protection. 


\section{ANALYSIS}

\subsection{APPROACH}

As a basis for evaluating the environmental implications of private power development in India, this report will examine a range of scenarios that represent different paths for meeting electricity service needs for economic and social development in India: (1) more vs. less private power generation as a proportion of the total utility mix and (2) more vs. less power needs unmet by utilities and met instead by self-generation. In estimating environmental implications of these paths, the report will focus on air emissions (particulates, $\mathrm{NO}_{x}, \mathrm{SO}_{2}$, and $\mathrm{CO}_{2}$ ), considering other impacts as well but generally assuming that they are roughly proportional to air emissions. The analysis rests substantially on very limited available data about differences between Indian public and private utilities in coal consumption per unit of power produced, as an indicator of private vs. public sector management effectiveness, together with implications for emissions. For example, according to CEA data, for a calorific value of coal above $5000 \mathrm{Kcal} / \mathrm{Kg}$, coal consumption by Calcutta Electric Supply Corporation (a private utility) is $0.15 \mathrm{Kg} / \mathrm{KWh}$, compared with a value in the range of $0.58-1.51 \mathrm{Kg} / \mathrm{KWh}$ for public utilities (CEA, 1990). Figure 1 shows the relationship between power plant efficiency, measured as specific coal consumption, and uncontrolled emissions per unit of electricity generated. Emissions are calculated based on pulverized fuel, dry bottom, and wall fixed technology (EPA, 1996), assuming a calorific value of Indian coal as $4200 \mathrm{Kcal} / \mathrm{Kg}$, containing 0.5 weight \% sulfur. A higher specific coal consumption (i.e., $>1 \mathrm{Kcal} / \mathrm{Kg}$ ) observed in the case of public utilities, indicates a thermal plant efficiency lower than 20\% (compared to the normal range of 30-35\%). As a result, uncontrolled air pollutant emissions are substantially lower for private than for public utilities per unit of electricity generated. A reduction in specific coal consumption from 0.91 (a typical for SEBs) to $0.68 \mathrm{Kg} / \mathrm{KWh}$ (i.e., an average for private utiiities) results in a 25 percent reduction in uncontrolled emissions. For example, for the same reductions in specific coal consumption, carbon dioxide emissions are estimated to decrease from 1284 tons/Gwh to 962 tons/GWh. The Plant Load Factor (PLF) is an important indicator of operational efficiency of thermal power plants. Today, the plant load factor of thermal power stations stand at $55.4 \%$ and $67.7 \%$ for SEBs and the central sector, respectively, compared to $78.3 \%$ in the privati sector (GOI, 1996). The plant load factor is the least in the case of captive generation, i.e., 36\% (TERI, 1996).

This report also considers available estimates of private sector roles in generating capacity additions (e.g., Table 2) but, due to uncertainties about what can actually be 


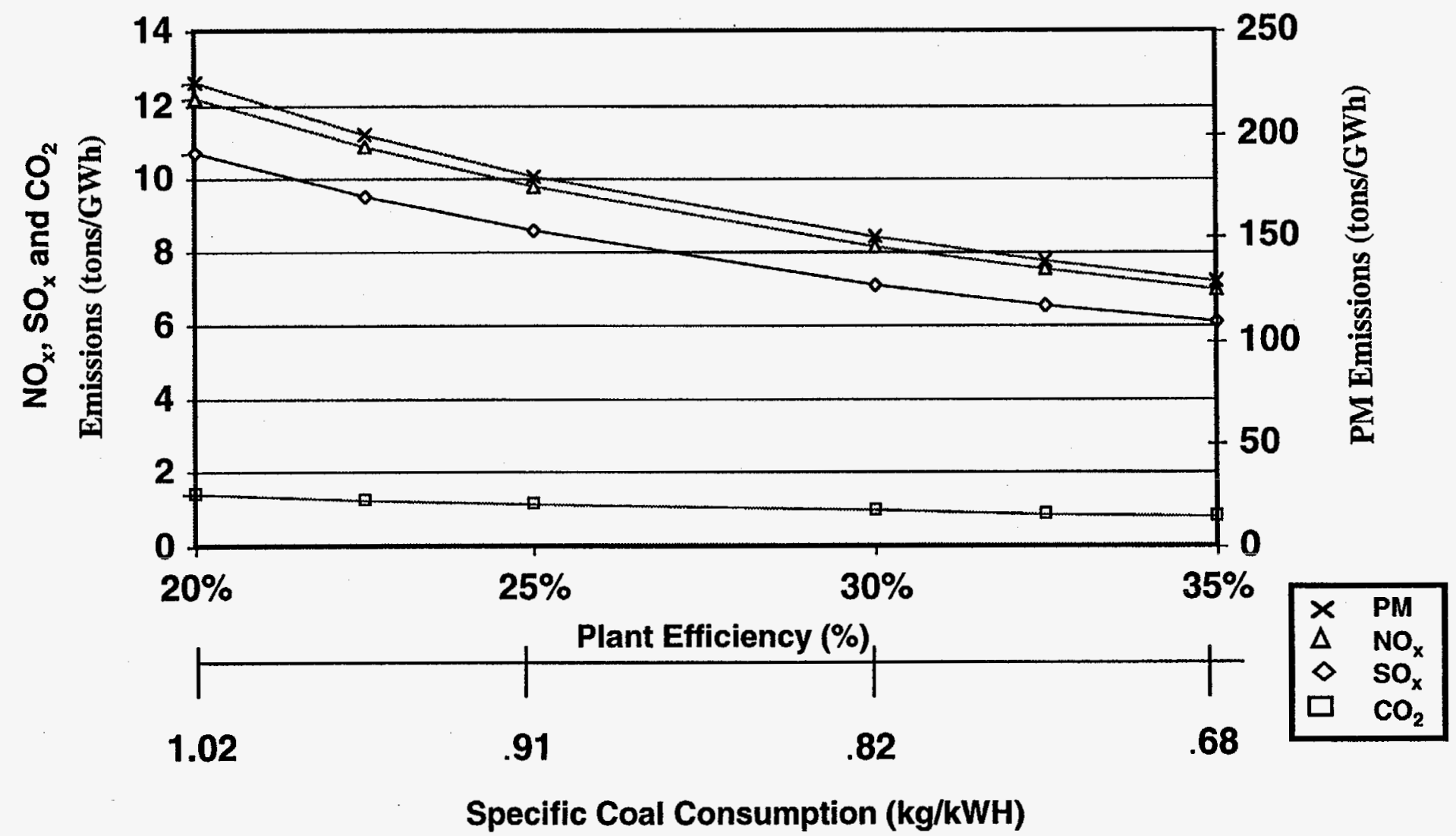

Note: $\mathrm{CO}_{2}$ emissions are in ' 000 tons/GWH

Fig. 1. Effect on uncontrolled air emissions due to the variation in specific coal consumption in Indian thermal power plants. 
expected, relies on scenario approximations of alternative paths rather than these quantitative estimates of comparative roles.

Essentially, the construction of emission estimates for a given time period in a given scenario proceeds as follows:

- Given a constant forecast of the total power need in that time period, assumptions are made about the shares of public power generation, private power generation for utilities, and self-generation in meeting that need.

- Uncontrolled emission factors for different fuel sources are estimated from EPA data, and controlled emission factors are based on plausible assumptions about control technologies (Tables 3 and 4).

- Differences in air emissions from private vs. public coal-fired power plants are estimated from current differences in the specific coal consumption for power plants in India, reflecting differences in average plant efficiency (assumed to be 30 percent and 34.5 percent for public and private utilities, respectively).

- The mix in generation resource/technology use is assumed to be constant between public and private sectors, based on available data about private power development proposals, i.e., Table 2 (a conservative assumption, since private power developments seem more likely to use low-impact fuel sources such as imported natural gas).

This approach permits a preliminary estimate of the qualitative environmental impacts of private power development in India (positive or negative, large or small), covering environmental pollution at both the point of power generation and at the point of end use. Other factors are then considered qualitatively to fine-tune the conclusions and recommendations.

\subsection{LIMITATIONS}

This approach is obviously limited in its reliability, for several reasons. First, the experience to date with private power generation in India is so limited that generalizing from this minuscule data base is dangerous. Second, the data incorporated in the analysis are limited to the few sources that could be located in the time period available. Third, a number of the simplifying assumptions are unsatisfying, compared with an ideal, such as estimating end use emissions due to industrial generation without estimating the additional contribution from small-scale diesel generators. 
Table 3. Uncontrolled emission factors (tons/GWh) for different resource based power generation technologies in India

\begin{tabular}{|c|c|c|c|c|}
\hline \multirow{2}{*}{ Pollutant } & \multicolumn{3}{|c|}{ Utilities } & \multirow{2}{*}{$\begin{array}{c}\text { Diesel } \\
\text { generators }\end{array}$} \\
\cline { 2 - 4 } & $\mathrm{Coal}^{\mathrm{a}}$ & Natural gas $^{\mathrm{b}}$ & Oil $^{\mathrm{c}}$ & \\
\hline $\mathrm{NO}_{\mathrm{x}}$ & 7.08 & 1.83 & 2.19 & 0.91 \\
\hline $\mathrm{SO}_{\mathrm{x}}$ & 6.2 & 0.00 & 14.34 & 4.54 \\
\hline $\mathrm{PM}_{\mathrm{CO}}$ & 130.5 & 0.08 & 0.94 & 0.09 \\
\hline
\end{tabular}

Note:

a Pulverized fuel, dry bottom, wall fixed, $7,579 \mathrm{Btu} / \mathrm{lb}$ heat rate, $0.5 \mathrm{wt} \%$ sulfur, $34.5 \%$ efficiency.

${ }^{\mathrm{b}}$ Combined cycle systems, $24,310 \mathrm{Btu} / \mathrm{lb}$ heat rate, $41 \%$ efficiency.

${ }^{c}$ No. 6 oil fired, normal firing utility boilers, $20,658 \mathrm{Btu} / \mathrm{lb}$ heat rate, $2.8 \mathrm{wt} \%$ sulfur, $35 \%$ efficiency.

${ }^{d}$ Distillate oil fired commercial/institutional/residential combustors, 19,163 Btu/lb heat rate, $0.7 \mathrm{wt} \%$ sulfur, $25 \%$ efficiency.

Table 4. Controlled emission factors (tons/GWh) for different resource based power generation technologies in India

\begin{tabular}{|c|c|c|c|c|}
\hline \multirow{2}{*}{ Pollutant } & \multicolumn{3}{|c|}{ Utilities } & \multirow{2}{*}{$\begin{array}{c}\text { Diesel } \\
\text { generators }^{\mathrm{d}}\end{array}$} \\
\cline { 2 - 4 } & $\mathrm{Coal}^{\mathrm{a}}$ & Natural gas $^{\mathrm{b}}$ & Oil $^{\mathrm{c}}$ & \\
\hline $\mathrm{NO}_{\mathrm{x}}$ & 3.54 & 0.549 & 0.656 & 0.91 \\
\hline $\mathrm{SO}_{\mathrm{x}}$ & 6.2 & 0.00 & 1.433 & 4.54 \\
\hline $\mathrm{PM}^{\mathrm{CO}}$ & 1.3 & 0.08 & 0.047 & 0.09 \\
\hline
\end{tabular}

Note:

${ }^{a}$ Pulverized fuel, dry bottom, wall fixed, 7,579 Btu/lb heat rate, $0.5 \mathrm{wt} \%$ sulfur, $34.5 \%$ efficiency, $50 \% \mathrm{NO}_{\mathrm{x}}$ and $99 \% \mathrm{PM}$ removal.

${ }^{b}$ Combined cycle systems, $24,310 \mathrm{Btu} / \mathrm{lb}$ heat rate, $41 \%$ efficiency, $70 \% \mathrm{No}_{\mathrm{x}}$ removal.

${ }^{c}$ No. 6 oil fired, normal firing utility boilers, $20,658 \mathrm{Btu} / \mathrm{lb}$ heat rate, $2.8 \mathrm{wt} \%$ sulfur, $35 \%$ efficiency, $70 \% \mathrm{NO}_{x}, 90 \% \mathrm{SO}_{2}$, and $95 \% \mathrm{PM}$ removal.

${ }^{d}$ Distillate oil fired commercial/institutional/residential combustors, 19,163 Btu/lb heat rate, $0.7 \mathrm{wt} \%$ sulfur, $25 \%$ efficiency. 


\subsection{SCENARIOS}

The analysis considers four scenarios. All four are keyed to the 1996 Central Electric Authority (CEA) forecast of electric power demand in India in the 2001-2012 period (Figure 2), in essence assuming that these forecasts accurately estimate electricity supply requirements for development and that they will be met by self-generation if reliable central sources are not available:

A: CEA Base Case -- the CEA estimate of private vs. public power generation at the end of the 9th, 10th, and 11th Five Year Plans (or 2001/2, 2006/7, and 2011/12), assuming that CEA's estimate of the current proportional contribution of industrial self-generation ( 7 percent) remains constant (Figure 3 ).

B: Realistic Base Case - the same total power requirements for development, but with the private sector share of total utility generation increasing from the current 4 percent to 6,8 , and 10 percent respectively (representing a "business as usual" response to constraints on expanding public sector generation) and the self-generation share increasing from the current 7 percent to 10,15 , and 20 percent, respectively (representing growing shortfalls in utility power supply compared with national needs) (Figure 4).

C: Optimistic Private Power Growth -- the same total power requirements, but a much larger private sector share: 25,50 and 75 percent respectively. Selfgeneration remains at the current 7 percent level. This scenario represents a very optimistic view of the potential contribution by private sector development to reducing shortfalls compared with the Realistic Base Case (Figure 5).

D: Realistic Optimistic Case -- the same total power requirements, but an intermediate rate of increase in the private sector share in utility power generation -- 10,20 , and 30 , respectively -- and a moderated rate of increase in power supply shortfalls and thus industrial self-generation $-9,12$, and 15 percent, respectively (Figure 6).

\subsection{SCENARIO RESULTS}

Air emissions associated with the four scenarios were calculated for both "uncontrolled emissions" and "controlled emissions" (Tables 5 and 6). Uncontrolled emissions represent an unrealistic worst case for air emissions but provide a rough gauge of differences between the scenarios in overall fuel cycle impacts such as solid waste emissions (since controls on air emissions essentially channel wastes into other streams). 


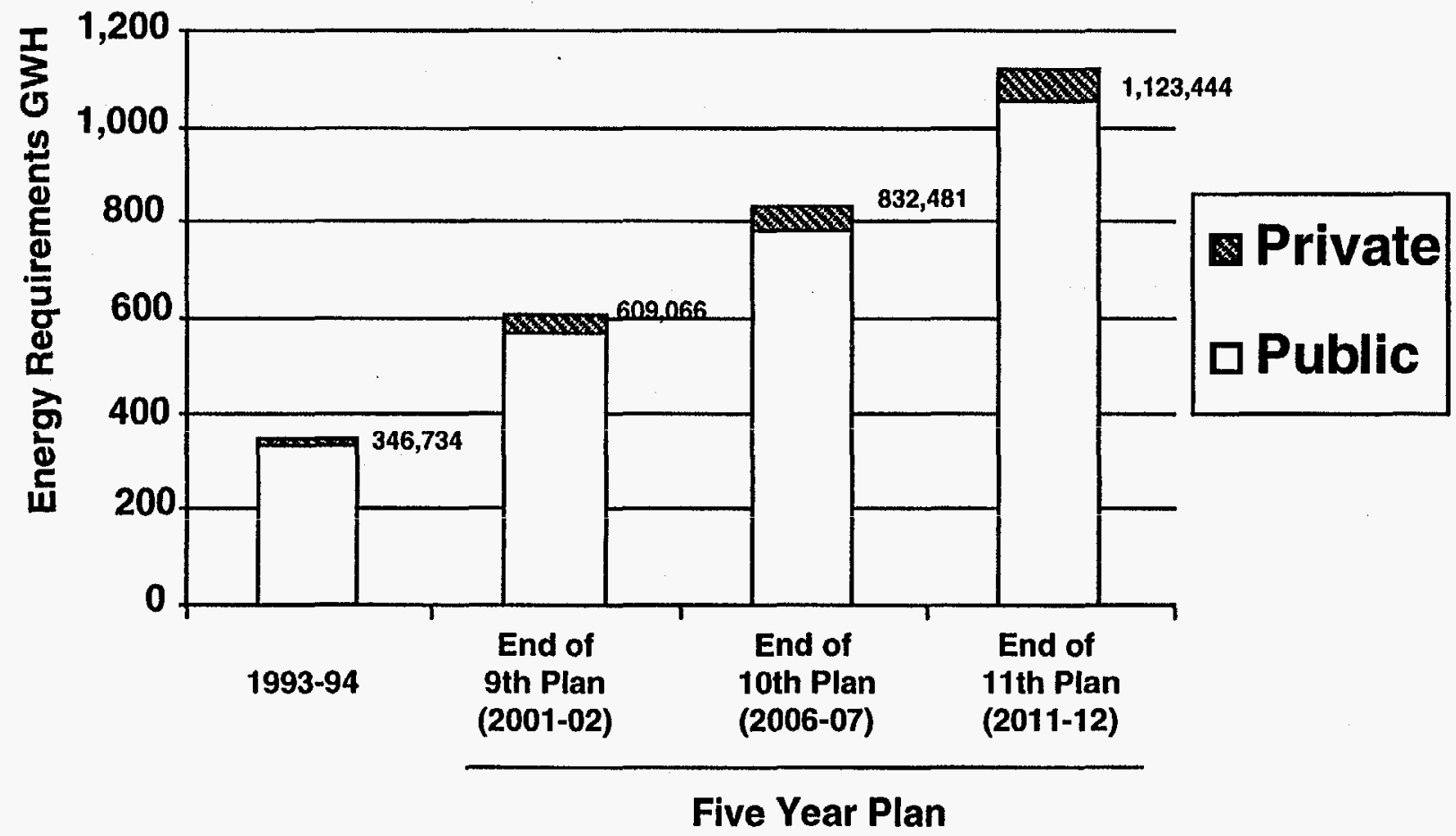

Source: CEA (1996)

Fig. 2. Forecast of energy requirements in India during 2001-2012. 


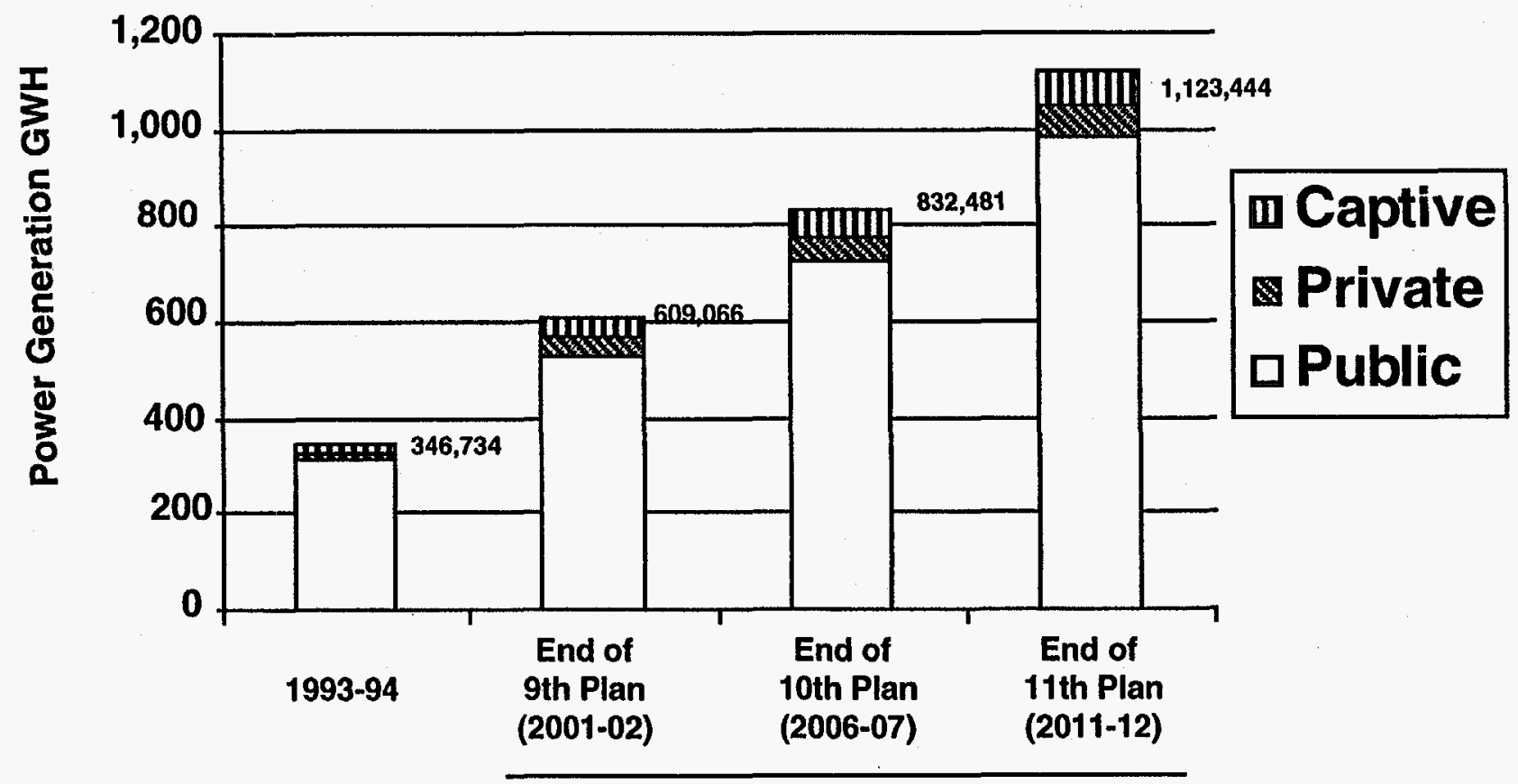

Five Year Plan

Source: CEA (1996)

Fig. 3. Distribution of sectoral power generation in India during 2001-2012: scenario A. 


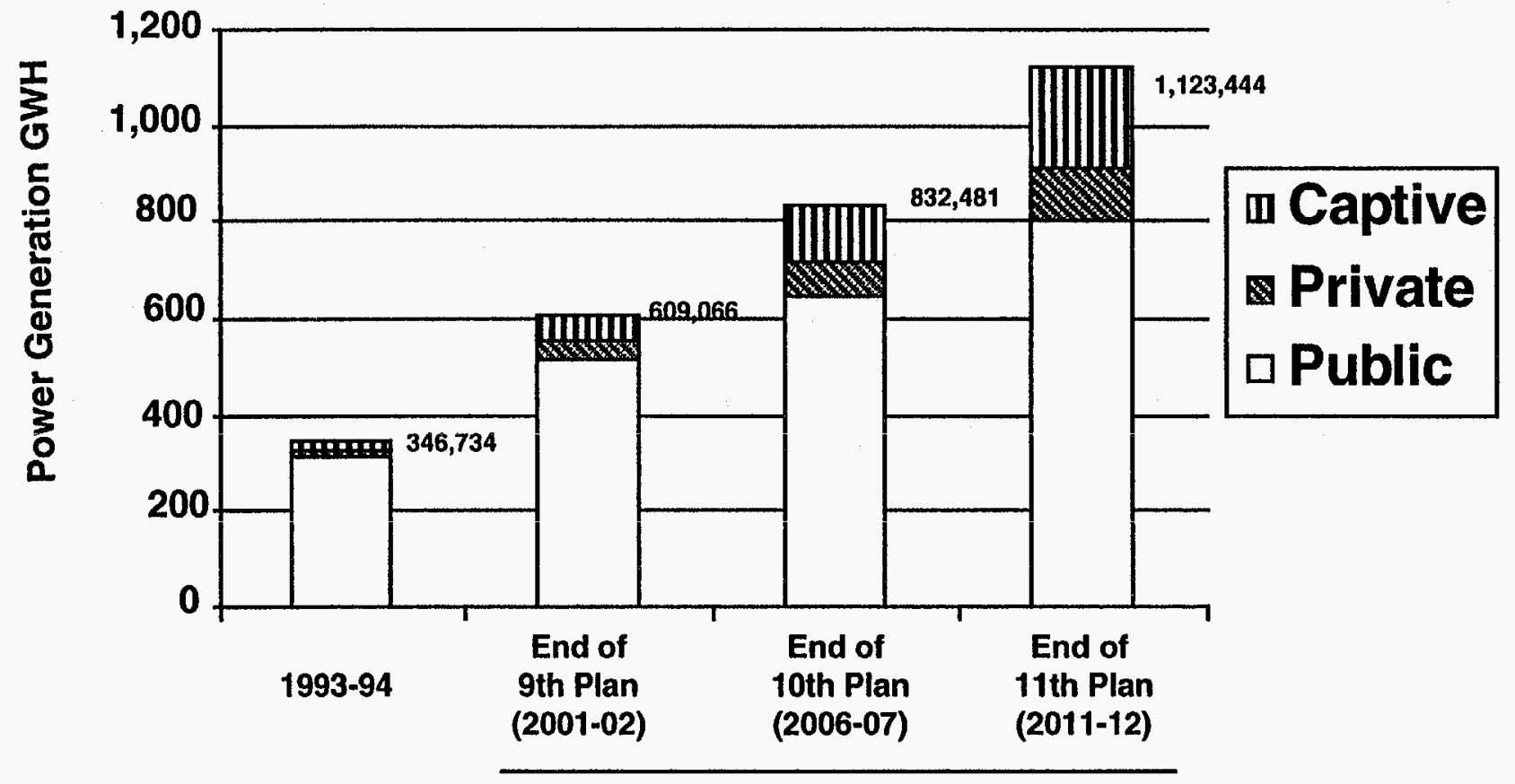

Five Year Plan

Source: CEA (1996)

Fig. 4. Distribution of sectoral power generation in India during 2001-2012: scenario B. 


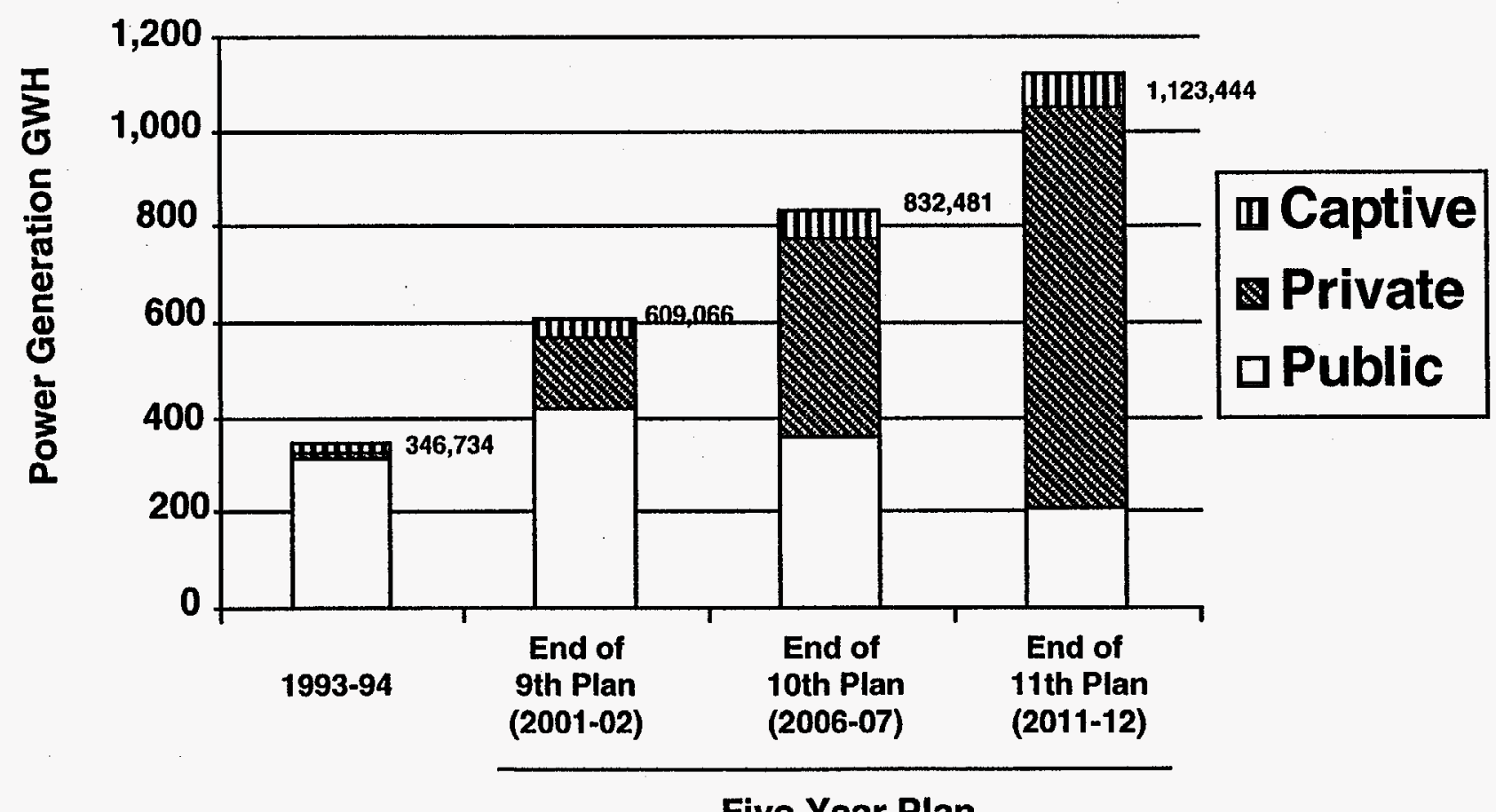

Source: CEA (1996)

Fig. 5. Distribution of sectoral power generation in India during 2001-2012: scenario C. 


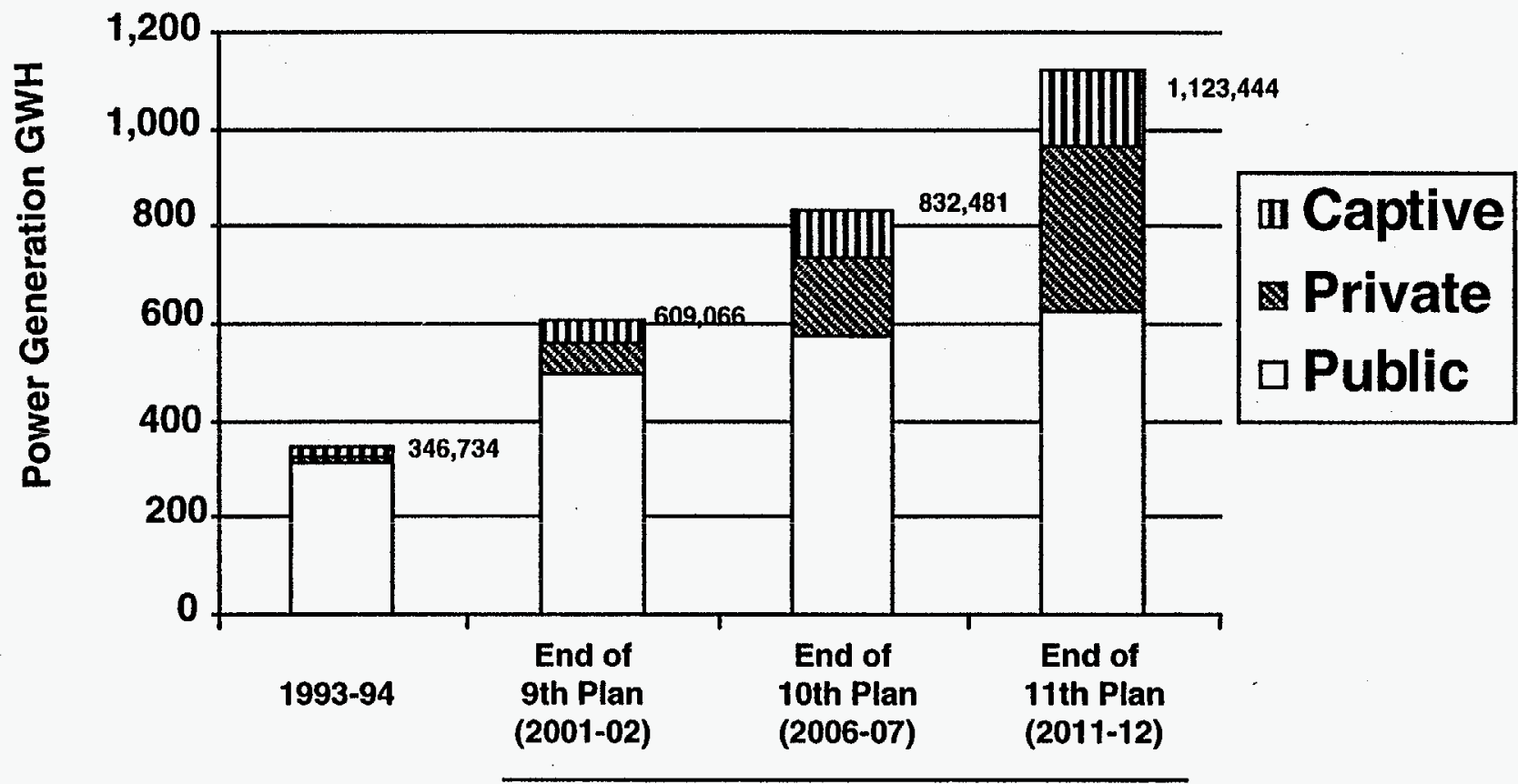

Five Year Plan

Source: CEA (1996)

Fig. 6. Distribution of sectoral power generation in India during 2001-2012: scenario D. 


\begin{tabular}{|c|c|c|c|c|c|c|c|c|c|c|c|c|}
\hline IEZ068 & $88 S \angle Z 8$ & EOLIZ6 & $010 \varepsilon 68$ & SI0I99 & $6 \mathrm{~L} \angle 0 \varepsilon 9$ & $066+\angle 9$ & $18+199$ & SI978t & $\varepsilon Z Z D L t$ & $\angle 1088 D$ & $8 \amalg L E 8 D$ & ${ }^{2} 02$ \\
\hline $00<26$ & $\neq 8 S \neq 6$ & SZE06 & $\nabla 8 \mathrm{~L} \rightarrow 0 \mathrm{I}$ & $6 \mathrm{LIZL}$ & SE8ZL & $I E I I L$ & IE9LL & SSESS & ZOESS & IOISS & $28 \angle 9 S$ & Wd \\
\hline$\angle 929$ & $\varepsilon \angle 09$ & $I \varepsilon \varepsilon 9$ & $\angle S 59$ & $62 \angle t$ & $0 \varepsilon 9 t$ & $8 S L t$ & $858 t$ & $\varepsilon Z S \mathcal{E}$ & $28+\varepsilon$ & $0 \mathcal{E S E}$ & $\varepsilon \mathcal{E S \mathcal { E }}$ & ${ }^{2} \mathrm{OS}$ \\
\hline LI9S & $189 \mathrm{~S}$ & $2 I S S$ & SEZ9 & $I \neq \varepsilon t$ & $6 S \mathcal{}$ t & S62t & $6[9 t$ & $90 \varepsilon \mathcal{E}$ & $862 \varepsilon$ & SGZE & $6 \angle E E$ & ${ }^{x_{\mathrm{ON}}}$ \\
\hline a & 2 & $g$ & $\mathrm{~V}$ & a & 2 & $\mathrm{~g}$ & $\mathrm{~V}$ & $a$ & 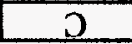 & $\mathrm{g}$ & $\mathrm{V}$ & \multirow{3}{*}{ słuęn ${ }_{I\left[O_{d}\right.}$} \\
\hline \multicolumn{4}{|c|}{ so!deuros } & \multicolumn{4}{|c|}{ So!deuras } & \multicolumn{4}{|c|}{ solyeuəas } & \\
\hline \multicolumn{4}{|c|}{ 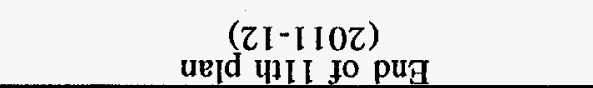 } & \multicolumn{4}{|c|}{$\begin{array}{c}\left(\angle 0^{-9} 900 z\right) \\
\text { urdd yl01 jo pug }\end{array}$} & \multicolumn{4}{|c|}{$\begin{array}{c}(20-1002) \\
\text { ued ut to jo pug }\end{array}$} & \\
\hline
\end{tabular}

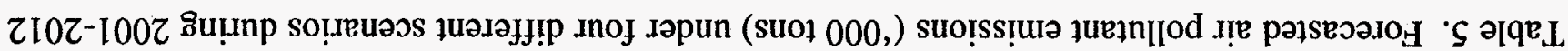

ASVD SNOISSIWH GATTO\&LNODNก 


\section{CONTROLLED EMISSIONS CASE}

Table 6. Forecasted air pollutant emissions ('000 tons) under four different scenarios during 2001-2012

\begin{tabular}{|c|c|c|c|c|c|c|c|c|c|c|c|c|}
\hline \multirow{3}{*}{ Pollutant } & \multicolumn{4}{|c|}{$\begin{array}{l}\text { End of 9th plan } \\
(2001-02)\end{array}$} & \multicolumn{4}{|c|}{$\begin{array}{l}\text { End of 10th plan } \\
(2006-07)\end{array}$} & \multicolumn{4}{|c|}{$\begin{array}{l}\text { End of 11th plan } \\
(2011-12)\end{array}$} \\
\hline & \multicolumn{4}{|c|}{ Scenarios } & \multicolumn{4}{|c|}{ Scenarios } & \multicolumn{4}{|c|}{ Scenarios } \\
\hline & $\bar{A}$ & $\bar{B}$ & $\bar{C}$ & $\overline{\mathrm{D}}$ & $\bar{A}$ & $\bar{B}$ & $\bar{C}$ & $\overline{\mathrm{D}}$ & $\bar{A}$ & $\bar{B}$ & $\bar{C}$ & $\bar{D}$ \\
\hline$\overline{\mathrm{NO}_{\mathrm{x}}}$ & 2233 & 2185 & 2069 & 2167 & 3056 & 2842 & 2527 & 2769 & 4128 & 3640 & 3003 & 3476 \\
\hline $\mathrm{SO}_{2}$ & 2943 & 2939 & 2873 & 2926 & 4025 & 3992 & 3797 & 3939 & 5433 & 5355 & 4949 & 5234 \\
\hline$\overline{\mathrm{PM}}$ & 10703 & 10416 & 8532 & 10062 & 14688 & 13127 & 7653 & 11675 & 19880 & 16212 & 4920 & 12950 \\
\hline $\mathrm{CO}_{2}$ & 483718 & 488017 & 474223 & 484615 & 661481 & 674990 & 630719 & 661015 & 893010 & 921703 & 827588 & 890231 \\
\hline
\end{tabular}

Assumptions

Coal*: $\mathrm{NO}_{\mathrm{x}}$ removal: $50 \%$ private, $30 \%$ public PM removal: $99 \%$ private, $80 \%$ public

Oil: $\quad \mathrm{NO}_{\mathrm{x}}$ removal: $70 \%$ for both public and private $\mathrm{SO}_{2}$ removal: $90 \%$ for both public and private PM removal: $95 \%$ for both public and private

Gas: $\quad \mathrm{NO}_{\mathrm{x}}$ removal: $70 \%$ for both public and private

${ }^{*} \mathrm{SO}_{2}$ not a significant issue for low-sulfur Indian or imported coals. 
Controlled emissions represent an approximation of a best case, assuming that both public and private power plants comply with international air emissions standards, using best available control technologies.

Essentially, the resulting numbers reflect two dominant factors, one informative and the other potentially misleading. First, emissions are higher where the public sector share of power plant generation is higher, because current data indicate that private power plants are operated more efficiently: i.e., they consume less coal to generate a given level of KWh than public power plants. Second, because diesel fuel produces less emissions without controls than coal power generation without controls, the uncontrolled emission estimates tend to indicate that central electricity generation shortfalls are good for the environment, because central coal-fired generation is replaced by less polluting diesel self-generation. The controlled emission tables deal with this factor by incorporating, realistically, emission controls for power plants but not for self-generation.

In the uncontrolled emissions case (Table 5), emissions are lowest where selfgeneration is the highest, which is probably a reliable indicator of volumes of solid and liquid wastes. They are also lower where the private sector share of power generation is higher. The differences, however, seem to be within the range of possible error in the estimation assumptions and parameters. In other words, the quantitative analysis of uncontrolled emissions shows no significant differences according to the share of private power development.

In the controlled emissions case (Table 6), the differences are considerably sharper. Note, for example, that for particulate materials (PM) Scenario C (optimistic private power growth) shows only about one-quarter of the total emissions in 2011/12 compared with the CEA base case; and the realistic optimistic case shows about two-thirds of the total emissions compared with the CEA base case and three-quarters compared with the realistic base case -- entirely due to assumptions about additional management efficiencies in power generation and greater effectiveness in reducing central power supply shortfalls.

\subsubsection{Private Power and Impacts of Power Generation in India}

This very limited analysis indicates, as would be self-evident, that as long as private power generation in India remains more efficient in power plant performance than public power generation, its air emissions will be less -- if the use of generation technologies is more or less comparable. Solid waste production will be about the same, public vs. private. 
Whether or not this general picture will remain valid. over the next several decades depends mainly on two factors: (1) incentives for private power developers to avoid public skepticism and criticism by complying carefully with environmental regulations and guidelines, under considerable public scrutiny, and (2) progress with electric utility reform, which may improve the management efficiency of public power generation. If the former factor is kept under control with the assistance of social monitoring, the latter can only be good for the Indian environment overall.

The major threat seems to be a possibility that, under conditions of a national power crisis, Indian government and society might relax conditions for private power development to a point where unscrupulous domestic entrepreneurs would enter the market with little concern about corporate image, building "quick and dirty" coal-fired power plants with few effective emission controls and little accountability. In this extreme case, private power development could be bad for the environment compared with public-sector development.

\subsubsection{Private Power and Environmental Quality in Urban Areas in India}

This analysis has attempted to address, in a very preliminary way, a possible relationship between private power development and urban environmental quality, related to the fact that local developmental activities in India will meet their electricity needs by selfgeneration if reliable central power supplies are not available. Uncontrolled emissions from diesel generators by industrial, commercial, and residential consumers are bad for the environment in India, compared with controlled emissions from central power plants, for two reasons. First, the lack of emission controls on small-scale generators generally means more total emissions as a result of the fact that emission-controlled central power supplies are limited. Second, the uncontrolled emissions occur in locations where air pollution is already the worst, added to such other sources as local vehicle emissions, rather than at power plant sites where ambient conditions are usually less critical. Even though diesel fuel tends to have less pollutants than coal, diesel generation produces more concentrated emissions than one might expect from characteristics alone, because its emissions are issued closer to people in the immediate area (Table 7). Moreover, some sources indicate that the sulfur concentration in Indian diesel fuel is considerably higher than that assumed here (i.e., 2-4 percent by weight rather than 0.7 percent).

As a result, to the degree that private power development is more successful in adding central power generation capacity in a given time period, it is likely to make a positive contribution to urban environmental quality in India. 
Table 7. Ratio of concentration of diesel generation to concentration of different utility based power generation technologies for various uncontrolled air pollutant emissions (for explanation, see Appendix)

\begin{tabular}{|c|c|c|c|}
\hline \multirow{2}{*}{ Pollutant } & \multicolumn{3}{|c|}{ Ratio of diesel concentration to } \\
\cline { 2 - 4 } & Coal & Natural gas & Oil \\
\hline $\mathrm{NO}_{\mathrm{X}}$ & 2 & 8 & 2 \\
\hline $\mathrm{SO}_{2}$ & 12 & NA & 5 \\
\hline $\mathrm{PM}$ & 0.01 & 18 & 2 \\
\hline $\mathrm{CO}_{2}$ & 20 & 35 & 21 \\
\hline
\end{tabular}

\subsection{OTHER ISSUES}

Other issues of importance, not directly addressed by the quantitative analysis, include:

- Differences in the mix of energy sources. Based on current trends, it appears that international private power development involves the use of more natural gas and more imported coal than the current mix of public power generation in India, along with more attention at the margin to renewable energy sources. Other things equal, this tends to reduce the trend in environmental emissions from power generation, but actual long-term trends remain uncertain.

- The role of foreign investment in private power development. It remains to be seen whether private power development in India will be based largely on international capital, which could favor the use of environmental best practices because of risks to the investors' international reputation.

- Progress with environmental management in Indian government and industry. The current judicial activism in environmental regulation and enforcement, together with expected impacts of the ISO 14000 certification process in Indian firms, provide reasons for cautious optimism about the environmental responsibility of private sector power developers in India in the future.

- Competitive pressures to reduce power supply costs. With electricity sector reform and restructuring, it is likely that incentives will increase for reducing generating costs in order to sell power in competition with other suppliers, and this could favor suppliers with smaller investments in environmental controls and inferior environmental performance, especially if the national power supply crisis intensifies. 


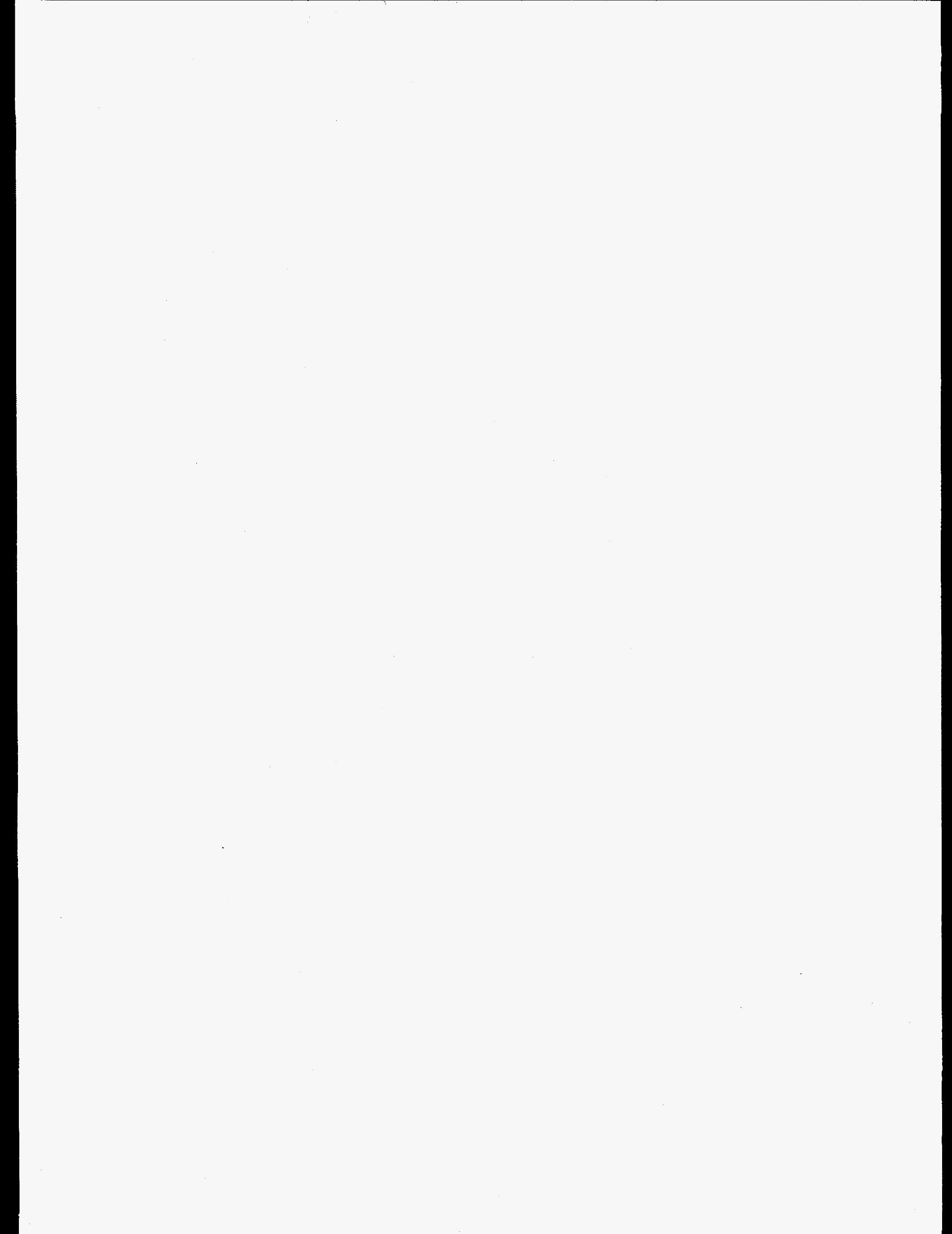




\section{CONCLUSIONS}

As a result of this very limited preliminary analysis, the following provisional conclusions can be drawn:

- Private power development will almost certainly make a positive contribution to environmental protection and management in India.

- In power generation, responsible environmental management will be driven more -- at least initially -- by social scrutiny and corporate image than by government regulation, but these are potent forces.

- To the degree that private power development improves the reliability of electricity services in polluted urban areas, it will contribute to improved environmental quality in those areas.

- The greatest environmental dangers from private power development in India lie in ad hoc domestic private sector responses to a national power crisis, based on coal use, if such a crisis provokes a "crash" private power expansion program with a relaxation of standards. 



\section{RECOMMENDATIONS}

To reduce uncertainties surrounding these conclusions and the analysis from which they are drawn, USAID/New Delhi should consider the following actions:

- At a modest level of effort, gather information to support a comparison of the management efficiency and environmental effects of equivalent public vs. private fossil-fueled power plants in India, with attention to possible differences between international and domestically financed private power plants.

- Enhance the information base about environmental effects in urban areas of unreliable central sources of electricity services, especially impacts of industrial, commercial, and residential self-generation.

- Continue to support policy initiatives in India that help to guard against less responsible behavior by private power developers, such as encouraging requirements for full environmental information disclosure. 



\section{REFERENCES}

Central Board of Irrigation and Power (CBIP), 1995. Power Development in India 199596, Council of Power Utilities, New Delhi, India, June.

Central Electricity Authority (CEA), 1996. CEA, 1995. Fifteenth Electric Power Survey of India, Ministry of Power, Government of India, New Delhi, July.

Central Electricity Authority (CEA), 1991. Performance of Thermal Power Stations, 1989/90, New Delhi, India.

Environmental Protection Agency (EPA), 1996. Compilation of Air Pollutant Emission Factors, AP-42, Office of Air and Waste Management, Research Triangle Park, NC.

Government of India (GOI), 1996. Economic Survey 1995-96, New Delhi.

Hagler Bailly Services, 1997. The Environmental Implications of Power Sector Reform in Developing Countries, prepared for USAID/G/EET.

Institute for Policy Studies (IPC), 1996. The World Bank's Juggernaut: The Coal-Fired Industrial Colonization of India's State of Orissa, Washington, DC, September.

K\&M Engineering and Consulting Corporation (KMECC), 1996. Opportunities, Barriers, and Recommendations Regarding the Deployment of U.S. Clean Coal Technologies to India, report prepared for Morgantown Energy Technology Center, Washington, DC, January

Tata Energy Research Institute (TERI), 1996. TERI Energy Data Directory and Yearbook 1996/97. New Delhi, India.

Tavoulareas, E. S. and Charpentier, J. P., 1995. Clean Coal Technologies for Developing Countries, World Bank Technical Paper No. 286, The World Bank, Washington, DC.

World Bank, 1996. India - Orissa Power Sector Restructuring Project, Report No. 14298IN, April 19.

World Bank, 1995. India - Orissa State Power Restructuring Project -- EA Category B, Environmental Assessment, Report No. E0077, February. 



\section{APPENDIX}

\section{EFFECTS OF EMISSIONS RELEASES ON EMISSION CONCENTRATIONS}

Although the emissions factors (tons of pollutants/GWh of electricity generated) are higher for coal combustion than diesel combustion, the emissions from coal-fired power plants are typically released into the atmosphere at greater heights above the ground than the emissions from diesel generators. The stack of a coal-fired power plant may be as tall as 300 meters, while the exhaust pipe from a diesel generator is typically only 1 or 2 meters above the ground. This difference in release heights causes a dramatic difference in local ground-level concentrations of pollutants. The emissions from the elevated stack are diluted appreciably by atmospheric diffusion and reach the ground downwind of the stack in much lower concentrations than at their point of release. In contrast, diesel emissions have little time and space to diffuse because they're released near the ground. Thus, this difference in release height compensates for the differences in emissions factors between coal combustion and diesel combustion.

As a means of analyzing these offsetting factors, the SCREEN3 air dispersion model (EPA, 1995) was used as a tool for quantitatively comparing the ground-level concentrations from the two types of releases. SCREEN3 uses a Gaussian plume model that incorporates source-related factors (e.g., stack height and diameter, exit velocity and temperature) and meteorological factors (e.g., wind speed, atmospheric stability) to estimate pollutant concentrations from continuously emitting sources. It is assumed that the pollutant does not undergo any chemical reactions, and that no other removal processes, such as wet or dry deposition, act on the plume during its transport from the source.

For this comparison, it was assumed that the release height from the coal-fired power plant was 100 meters and the release height from the diesel generators was 1 meter. It should be noted that the modeling implicitly assumes that enough diesel generators are located at a single location to generate the same amount of electricity as a coal-fired power plant if it were located at that location. Concentrations predicted by SCREEN3 at 1000 meters downwind of the sources were used. This distance was used to allow the emissions from the elevated source to reach the ground and provide a good basis for comparison. Otherwise, concentrations adjacent to the diesel generators would be extremely high, while ground-level concentrations adjacent to the elevated stack would be zero.

Table 7 (see Section 4.4.2) presents the results of the air dispersion modeling. Specifically, the table displays ratios of concentrations predicted for different utility-based 
power generation technologies (i.e., coal, natural gas, and oil) compared with concentrations predicted for diesel combustion. The reason that absolute concentrations are not given is that they would not be meaningful because the emissions factors are ratios themselves rather than specific quantities of emissions. The results indicate that groundlevel concentrations of oxides of nitrogen $\left(\mathrm{NO}_{x}\right)$ from diesel combustion would be approximately double the corresponding concentrations from coal combustion, and 18 times for particulates from gas-based generation.

It is to be noted that for regional and global effects such as acid deposition and global warming, respectively, the emissions factors themselves should be used in the comparison without performing the air dispersion modeling. In fact, elevated releases allow greater transport and time for chemical transformations to occur than ground-level releases so that they contribute even more to acid deposition than just the concentration would indicate.

\section{Reference}

1. U.S. Environmental Protection Agency (EPA), 1995. SCREEN3 Model User's Guide, Office of Air Quality Planning and Standards, Technical Support Division, Research Triangle Park, NC, July. 


\section{INTERNAL DISTRIBUTION}

1. L.W. Baxter

2. G. E. Courville

3. T. R. Curlee

4. S. Das

5. S. B. Floyd

6. L. N. McCold

7. R. L. Miller

8. R. M. Reed

9. D. E. Reichle
10. D. T. Rizy

11. G. T. Scudder

12. R. B. Shelton

13. J. VanCoevering

14. T. J. Wilbanks

15. S. B. Wright

16. Central Research Office

17. Document Reference Section

18. Laboratory Records (RC)

\section{EXTERNAL DISTRIBUTION}

19. Dr. Lilia A. Abron, President, PEER Consultants, P.C., 1000 N. Ashley Drive, Suite 312, Tampa, FL 33602

20. Dr. Thomas E. Drabek, Professor, Department of Sociology, University of Denver, Denver, CO 80208-0209

21. Dr. Stephen G. Hildebrand, Director, Environmental Sciences Division, Oak Ridge National Laboratory, P.O. Box 2008, Oak Ridge, TN 37831-6037

22. Mr. P. Richard Rittelmann, FAIA, Executive Vice President, Burt Hill Kosar Rittlemann Associates, 400 Morgan Center, Butler, PA 16001-5977

23. Dr. Susan F. Tierney, The Economic Resource Group, Inc., One Mifflin Place, Cambridge, MA 02138

24. Dr. C. Michael Walton, Ernest H. Cockrell Centennial Chair in Engineering and Chairman, Department of Civil Engineering, University of Texas at Austin, Austin, TX 78712-1076

25-26. OSTI, U.S. Department of Energy, P.O. Box 62, Oak Ridge, TN 37831

27. ORNL Site Manager, DOE/ORO, P.O. Box 2008, Oak Ridge, TN 37831-6269

28-80. Global Change and Developing Countries Program distribution extra copies to T. J. Wilbanks, $4500 \mathrm{~N}, 130$ 